\title{
A RECONNAISSANCE GEOCHEMICAL SURVEY IN THE PROTEROZOIC-PHANEROZOIC PLATFORM SUCCESSION OF THE PEARY LAND REGION, NORTH GREENLAND
}

\author{
M. Ghisler, N. Henriksen, A. Steenfelt and H. Stendal
}

A regional geochemical reconnaissance survey based on stream sediments was an integral part of the systematic geological mapping of eastern North Greenland in 1978. The purpose was to provide information for an evaluation of the mineral potential and to obtain general geochemical data. A total of 448 stream sediment samples were collected, representing a wide geographic spread. The distribution of sample localities is shown on fig. 28 and the stratigraphical distribution is shown on fig. 29. All participating geologists and their assistants have contributed to the sampling programme.

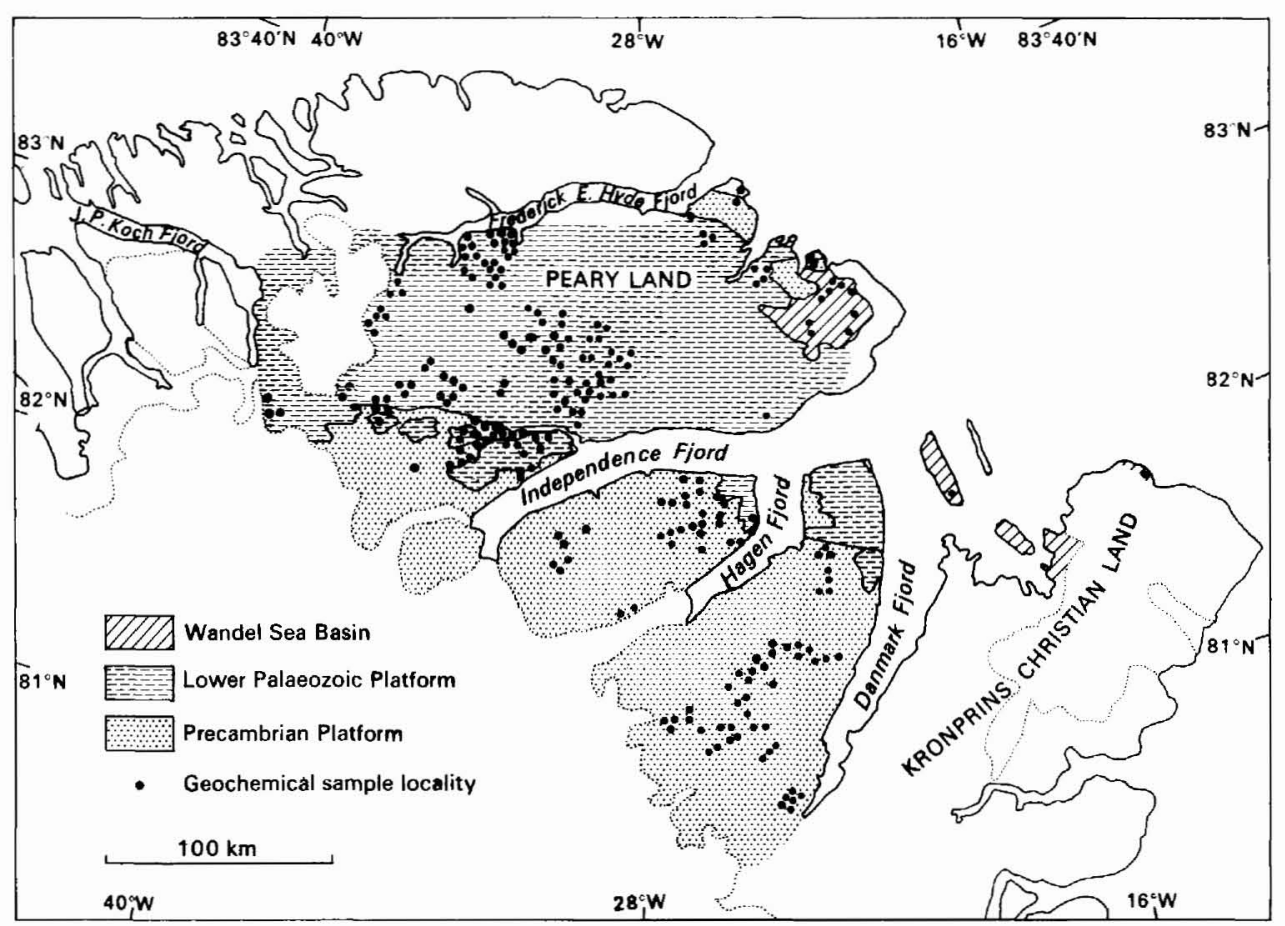

Fig. 28. Sketch map showing distribution of geochemical sample localities. 
STRATIGRAPHICAL UNIT

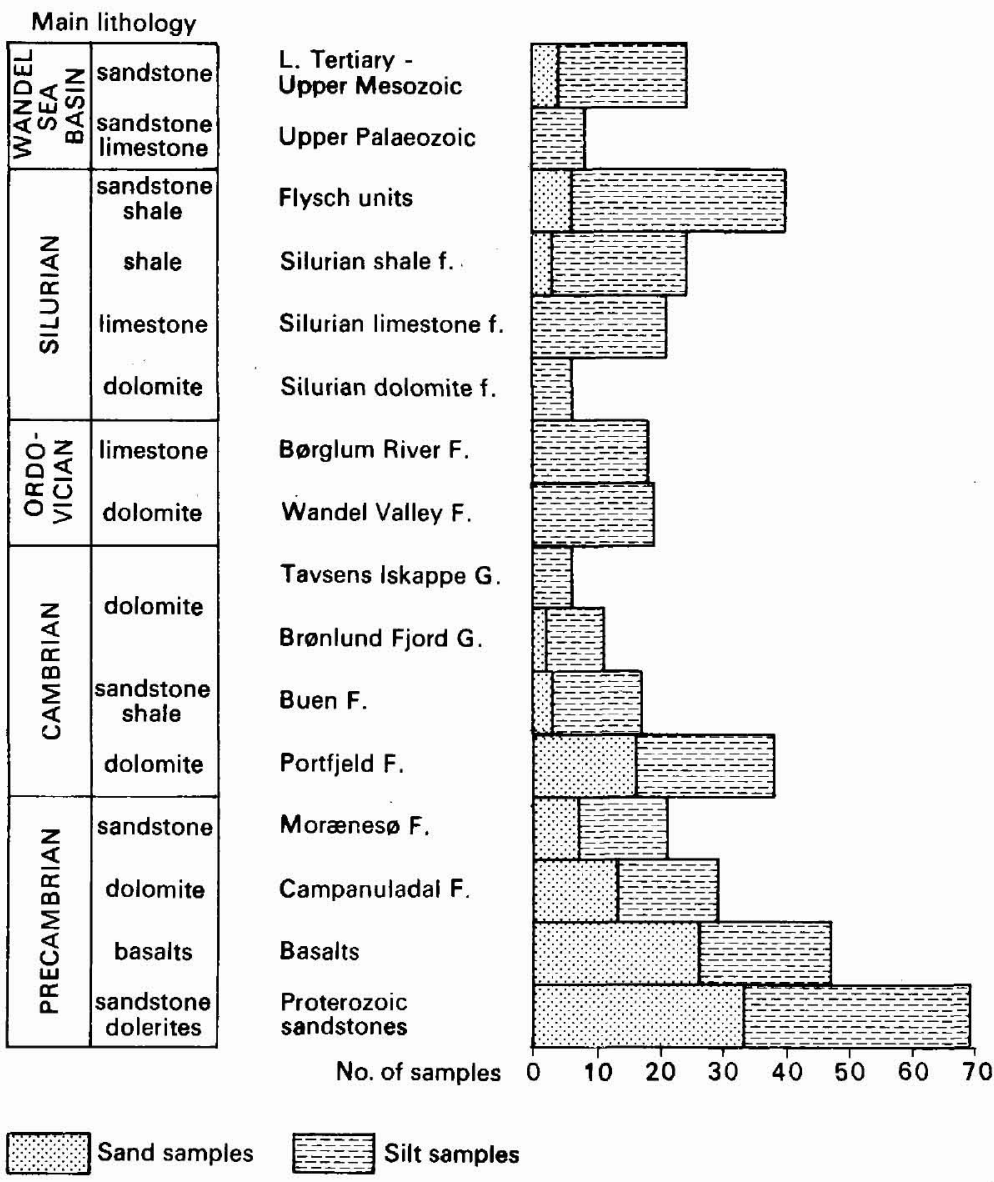

Fig. 29. Stratigraphical distribution of geochemical samples.

The Peary Land region contains approximately an $8000 \mathrm{~m}$ thick succession of gently dipping Proterozoic and Lower Palaeozoic platform deposits. These grade northwards into basinal clastic sediments, which are folded and metamorphosed into the east-west trending North Greenland fold belt (Dawes, 1976). Upper Palaeozoic to Lower Tertiary sediments of the Wandel Sea Basin rest with a major unconformity on Silurian flysch deposits. Fig. 30 gives a simplified litho-stratigraphical succession of the units in the Peary Land region, detailed descriptions of which are given by various geologists elsewhere in this report.

\section{Mineralisations}

Copper indications are found at different levels in the Proterozoic rocks. These include (a) numerous centimetre thick layers of malachite impregnated sandstone in the uppermost 
part of the Proterozoic sandstone west of Øvre Midsommersø (Clemmensen). Malachite staining is noted from other localities, always occurring close to dolerite sills or dykes (H. F. Jepsen, J. Collinson).

(b) $0.5-1 \mathrm{~cm}$ thick 'veins' of massive bornite in the matrix of the tillite west of Øvre Midsommersø (H. F. Jepsen).

(c) malachite stained lenses a few millimetre thick in dolostones at two stratigraphic levels in the upper part of Morænesø Formation west of Øvre Midsommersø (L. Clemmensen).

(d) malachite staining in the cross-bedded sandstones of the Campanuladal Formation on the west side of Hagen Fjord (L. Clemmensen).

(e) joints with malachite are found at many places within the basalts of Mylius-Erichsen Land. In addition malachite and native copper occurs in geodes in the middle part of the lava series (H. F. Jepsen).

\section{Sampling programme}

The intention of the sampling programme was to obtain samples from as many lithological and stratigraphical units as possible and to get a regional spread of sampling localities. Sampling was undertaken in relation to the local drainage system and generally streams of medium to small size were chosen, as these offer the best possibility for correlation to a specific 'source area'.

On a regional scale samples collected were relatively evenly spaced between Danmark Fjord and Frederick E. Hyde Fjord, but the sampling density locally varies considerably (fig. 28). Up to 10 samples have been collected within one $10 \times 10 \mathrm{~km}$ square but the sample density is usually much lower. This clearly indicates the reconnaissance character of the programme.

Double samples have been taken at many localities to evaluate the significance of variation of the metal content. In all, approximately $20-25$ per cent of all samples represent duplicates taken within $10-20 \mathrm{~m}$ distance from the first sample.

Two types of stream sediments were collected - sand and silt. It is necessary to combine these two sample media because of the fact that elements mainly occurring in resistant minerals are found in sand, whereas elements contained in easily weathered minerals usually are concentrated in the silt fraction.

The silt samples are of approximately $200 \mathrm{~g}$ of material, whereas the sand samples each were 1 litre. The following information was also noted at each locality: type of sample, stratigraphical level, lithology of bedrock in catchment area, stream width, colour of stream sediment and UTM coordinates.

\section{Laboratory investigations}

\section{Sand samples}

As illustrated in the flow sheet of fig. 31 the sand samples were sieved through a $1 \mathrm{~mm}$ screen. The minus $1-\mathrm{mm}$ fraction was preconcentrated by hand with a pan and further separated by heavy liquid (bromoform $\mathrm{d}=2.89 \mathrm{~g} / \mathrm{cm}^{3}$ ). Polished sections were prepared from the heavy mineral concentrates for opaque mineral study under reflected light. With a hand Wilke-magnet (Bentz \& Martini, 1968, p. 33) the heavy mineral concentrates were 


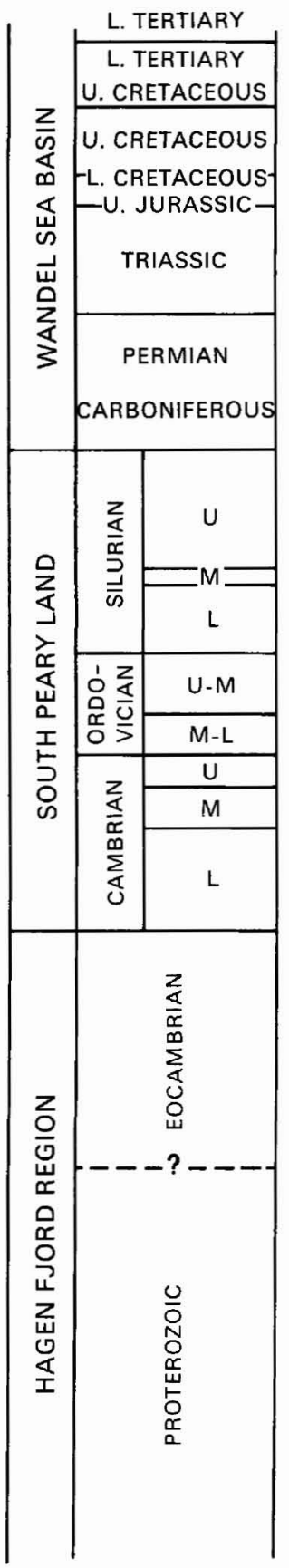

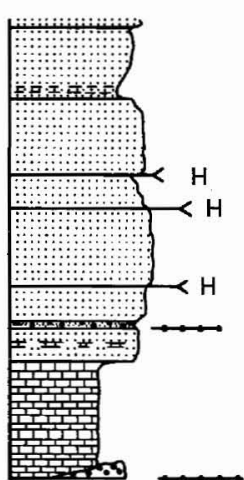

Thyra $\emptyset$ Formation

Herlufsholm Strand Formation

Nakkehoved Formation

Ladegårdsåen Formation

Dunken Formation

Parish Bjerg Formation

Midnatfjeld Formation

Mallemuk Mountain Group

Silurian flysch

Silurian shales + carbonate mounds

Silurian limestones

Silurian dolomites

Børglum River Formation

Wandel Valley Formation

Tavsens Iskappe Group

Brønlund Fjord Group

Buen Formation

Portfjeld Formation

Fyns Sø Formation

Morænesø Formation

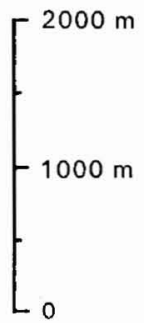

2000

in

地

Campanuladal Formation

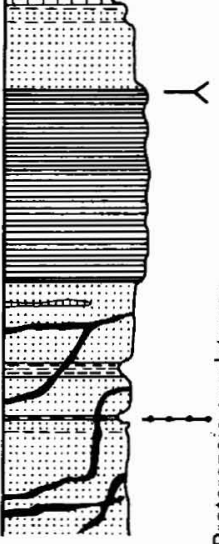

\section{$\mathrm{H}$}

Basalts

Quartzitic sandstones

Feldspathic sandstones

Sandstones

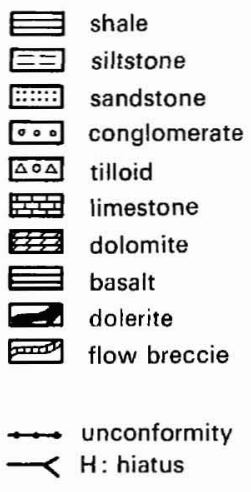

Fig. 30. Simplified litho-stratigraphical succession of units in the Peary Land region, detailed descriptions of which are given elsewhere in this report. 


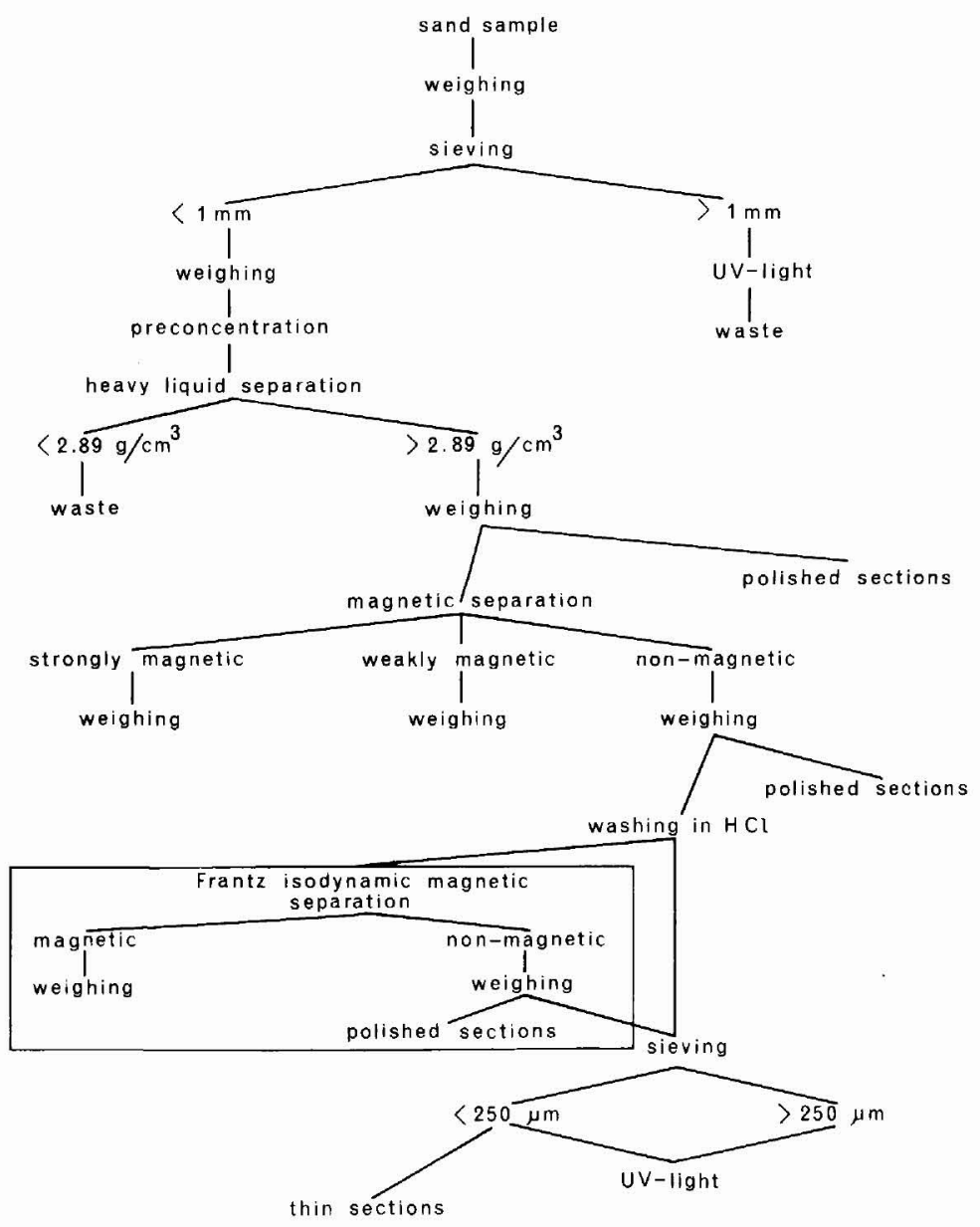

Fig. 31. Flow sheet showing the laboratory procedure for sand samples. Operations in frame only for samples rich in pyroxene.

separated into three different fractions: (1) a magnetite-titanomagnetite fraction, (2) an ilmenite-hematite fraction and (3) a non-magnetic fraction. The non-magnetic fraction of samples supposed to be rich in pyroxenes was run through a Frantz isodynamic magnetic separator. Polished sections were prepared of the non-magnetic fractions for investigations in transmitted light, thin sections in 'Clearex' $(n=1.66)$ were prepared of the minus $250-\mu \mathrm{m}$ fraction after treatment of the samples in hot diluted $\mathrm{HCl}$ to clean off coatings of $\mathrm{Fe}-\mathrm{Mn}$ oxides on the grains. The non-magnetic fraction as well as the plus $1-\mathrm{mm}$ fraction were investigated under ultraviolet light.

The heavy mineral concentrates (132) form on average 1 per cent (by weight) of the sieved sand samples. The highest amount of heavy minerals (1.75 per cent) is found in samples originating from the sediments and dolerites of the Proterozoic sandstones and the 
overlying basalts (fig. 30), whereas a content of 0.7 per cent occurs in the samples derived from Morænesø and Campanuladal Formations. Sand samples from the Portfjeld Formation give a value of 0.3 per cent whilst samples from Cambrian to Silurian rocks amount to only 0.03 per cent, except for samples from the lowermost Palaeozoic rocks north of G. B. Schley Fjord, which yield higher figures.

The main portion of the samples $(80)$ belong to the Precambrian terrains.It is thought that the heavy minerals mainly originate from the dolerites and basaltic lavas and to a lesser extent from the sediments. The heavy minerals are coarse-grained and angular in samples dominated by doleritic constituents, whereas samples mainly representing heavy minerals from the sandstones are more fine-grained and rounded. Some general statements and regional considerations are possible.

(a) The amount of heavy minerals in samples from the Proterozoic sandstones and the dolerites averages 1.75 per cent (by weight) and represents the highest figure for any of the stratigraphic units sampled. The non-magnetic fractions form 70-75 per cent (by weight) of the concentrates. Pyroxenes (hypersthene, augite, diopside) are the dominant silicate group, and epidote group minerals are always present and may in places be dominant. Minor but characteristic constituents are olivine, amphiboles, apatite and zircon. The content of Fe-Ti oxides seems to be rather constant throughout the region, magnetite-titanomagnetite being more important than ilmenite-hematite. Sulphides such as pyrite, chalcopyrite and others are scarce.

(b) The sand samples from the basalt areas contain 50 per cent more heavy minerals in Mylius-Erichsen Land than in J. C. Christensen Land, reflecting a decreased thickness of the lavas in the latter area. Fe-Ti oxides form 25 per cent (by weight) of the heavy minerals in Mylius-Erichsen Land, but only 15 per cent in J. C. Christensen Land. There is also a geochemical difference between analysed samples in the two areas. Magnetite-titanomagnetite forms the most important group in Mylius-Erichsen Land, whereas ilmenite-hematite is dominant in J. C. Christensen Land. The silicates are dominated by pyroxenes with hypersthene the most important. Epidote, zoisite, hornblende, actinolite, apatite and zircon are further characteristic constituents.

(c) In the Morænesø Formation and Campanuladal Formation the Fe-Ti oxides are strongly oxidised, and the magnetite fraction is generally only represented by small amounts. Pyrite framboides and bigger pyrite grains occur, as well as chalcopyrite. Epidote, diopside, hypersthene, apatite, olivine, rutile and sphene are identified in samples from these formations. One sample from south-east Mylius-Erichsen Land representing disintegrated rock material from the Campanuladal Formation and possibly also the Fyns Sø Formation contains anomalous amounts of chalcopyrite, associated with framboidal pyrite.

(d) Only a few samples from the Phanerozoic areas have so far been investigated. Pyrite showing framboidal textures as well as chalcopyrite and other unidentified sulphides have been observed.

Pyrite, chalcopyrite and other sulphides are well preserved in the sands and thus survive chemical disintegration under arctic conditions (cf. Stendal, 1979). 


\section{Silt samples}

The samples were dried and sieved into three grain size fractions: $<75 \mu \mathrm{m}, 75-250 \mu \mathrm{m}$, and $>250 \mu \mathrm{m}$. The two finer fractions will be analysed at Risø National Laboratory using delayed neutron counting (DNC) for U determinations and using isotope excited X-ray fluorescence (EDX) for determinations of the following elements: $\mathrm{K}, \mathrm{Ca}, \mathrm{Ti}, \mathrm{V}, \mathrm{Cr}, \mathrm{Fe}, \mathrm{Ni}$, $\mathrm{Cu}, \mathrm{Zn}, \mathrm{Ga}, \mathrm{Pb}, \mathrm{Sr}, \mathrm{Rb}, \mathrm{Y}, \mathrm{Zr}, \mathrm{Nb}$, Th.

The $<75 \mu \mathrm{m}$ fraction will be further analysed by atomic absorption spectrophotometry for $\mathrm{As}, \mathrm{Ba}, \mathrm{Bi}, \mathrm{Co}, \mathrm{Sb}$. Selected samples will be analysed for additional elements at the University of Copenhagen.

The $<150 \mu \mathrm{m}$ grain size fraction of 42 silt samples have been preliminarily analysed by DNC and EDX. The analysed samples are mainly derived from the uppermost lithological/stratigraphical units indicated on fig. 29.

The analytical results compare well with comparable studies from East Greenland (Steenfelt \& Kunzendorf, 1979) and Washington Land (Steenfelt, 1978). As in these two surveys the stream silt samples of the present survey reflect the geochemistry of the bedrock of the catchment area. For example 16 samples collected within one lithological unit (the Ladegårdsåen Formation of the Wandel Sea Basin) are close to each other in composition whereas they differ significantly from samples collected in the overlying Herlufsholm Strand Formation (Håkansson, this report). In the latter the presence of black shales is clearly expressed by increased (factor 2-3) concentrations of base metals and $U$ in the stream silt. None of the samples so far analysed indicate anomalies.

\section{Conclusions}

1. The geochemistry of the silt samples reflects bedrock composition of the catchment areas. This is in agreement with earlier regional geochemical surveys in Greenland.

2. The heavy mineral concentrates obtained from the sand samples contain common resistent minerals and a number of unaltered sulphides. The latter are readily disintegrated elsewhere.

3. The collection of stream sediments in eastern North Greenland has provided important information on the geochemistry of the bedrock geology and established one distinct $\mathrm{Cu}$ anomaly. It would appear worthwhile to continue the sampling programme in 1979-1980.

\section{References}

Bentz, A. \& Martini, H. J. 1968: Lehrbuch der angewandten Geologie. 2,1, 1355 pp. Stuttgart: Ferdinand Enke.

Dawes, P. R. 1976: Precambrian to Tertiary of northern Greenland. In Escher, A. \& Watt, W. S. (edit.) Geology of Greenland, 249-303. Copenhagen: Geol. Surv. Greenland.

Steenfelt, A. 1978: Reconnaissance drainage sampling for geochemical exploration, Washington Land 1976. GGU internal report.

Steenfelt, A. \& Kunzendorf, H. 1979: Geochemical methods in uranium exploration in northern East Greenland. In J. R. Watterson (edit.) Geochemical exploration 1978. Proceedings .7th Int. Symp. Exploration Geochemistry, April 1978.

Stendal, H. 1979: Geochemical copper prospecting using inorganic drainage sediments in central East Greenland $\left(72-74^{\circ} \mathrm{N}\right)$. Trans. Instn. Min. and Metall. B (in press). 